\title{
Trademark Ownership by the Local Government of the Special Region of Yogyakarta: A Model for Municipal Ownership of Intellectual Property Rights
}

\author{
Budi Agus Riswandi \\ Faculty of Law Universitas Islam Indonesia \\ budiagusr@uii.ac.id
}

\begin{abstract}
This article aims at elaborating the trademark ownership by the local government in Yogyakarta. As an effort to leverage the region's historical status in order to add value to products made in this region, the Special Region of Yogyakarta (the "DIY" or the "DIY Government") has registered its trademarks like "Jogjamark" and " $100 \%$ Jogja." However, there remains a question as to wether the DIY Government have the same rights and obligations concerning intellectual property as private entities, as longa a municipal government is concerned. Generally, a public legal entity is subject to the same laws, with both rights and obligations, as any other legal entity. In this context, the local government of the DIY's registration of these marks clearly confirms that the Local Government of the DIY is the trademark owner of those trademarks. This registration requires the question as to whether this government entity can legally own registered trademarks or not. In addition, even if the registration is legal, to what extent can the local government use and protect its intellectual property? This paper will address these two issues through an empirical research study, and determines that as a legal entity, the local government can and should own trademarks for the benefit of its population.
\end{abstract}

Keywords: Ownership; Trademark; Intellectual Property; Local Government Licencing 


\section{A. Introduction}

Rapid industrial development and globalization have tightened competition markets and triggered various kinds of unfair competition practices. The tightness of this trade environment may result from the abundance of similar products marketed by several countries at a relatively low cost. As the unfair competition has dramatically increased, including infringing on intellectual property, such infringement by low quality "knock offs" harm consumers and dilute brands.

In this reality, several strategies and policies have appered globally in industrial and trade development. One of the approaches to fight against unfair business practices is strategic collaboration between government and business actors. This collaboration can take many innovative forms. For government's part, innovation action may be manifested by promulgating polices to support the creation of competitive products and prevent unfair competition. Meanwhile, for business actors, innovative action may be manifested with implementation of good business ethics and creation of innovative products.

Encouraging industrial and business activity, Indonesian government always encourages local competitive products and prevents unfair business practices, not only in the national level but also in the local regional levels. One of the initiatives is the DIY Government's registration of the trademarks Jogjamark and 100\%Jogja, co-branding local products of the special region.

\section{B. The DIY Government; a Public Legal Entities with Intellectual Property Rights}

The study of public entities as distinct legal subjects is important in understanding their role in society. The position a legal entity shall imply to legal rights and obligations. Savigny has proposed the notion of fiction from which a legal person enjoys rights and bears obligations as creatures who have free will. However, because fictional legal entities does not have freewill, subjectively, their rights and 
obligations are based on the concept of a legal fiction. ${ }^{1}$ From this perspective, then legal entity shall be considered as an artificial social structure. This means that legal entities, as social organizations and structures that have legal capacity and contractual capacity, can act independently in legal transactions. Whilest legal entities are not born naturally like individuals. Under the law they are established by articles of association, allowing the conduct of legal transactions. ${ }^{2}$

Legal entities are considered artificial legal constructs consisting of assets intended for several purposes or groups of individuals, thereby forming a legal order that is recognized by the law. ${ }^{3}$ Legal entities have the capacity through registration to conduct legal acts, namely legal transactions. ${ }^{4}$ Therefore, legal entities have two essential aspects: (1) legal capacity and (2) ability to conduct legal acts.

To have legal capacity, the entity shal have a legal personality. Jose L. De Benito argued that a legal entity is related to the concept of juridical personality, which is usually owned by group of individuals who work collectively in a social group or social organization with a specific purpose. ${ }^{5}$ Benito confirms that legal personality is not a single subject of law, but rather is comprise of fiveessential elements. According to him, to be recognized as a subject of law, an entity shall fulfill the following requirements: (1) plurality of individuals; (2) cooperation; (3) organization; (4) exclusive patrimonial capacity; and (5) corporate purpose. ${ }^{6}$

1 Savigny, F. C. (1840). Modern Roman Law System. (J. M. Poley, Trans.) Berlin: Veit, p.304.See alsoAdriano, E. A. (2015). The Natural Person, Legal Entity or Juridical Person and Juridical Personality. The Penn State Journal of Law \& International Affairs, 4(1), 363-391. Retrieved from https: / / elibrary.law.psu. $\mathrm{edu} / \mathrm{jlia} / \mathrm{vol} 4 / \mathrm{iss} 1 / 17 /$, accessed on October $20^{\text {th }}, 2019$ at 8:14 A.M

2 Tičar, B. (2016). Towards an Innovative Classification of Legal Persons. Journal of Criminal Justice and Security, 2, p. 164-177. Retrieved from https: / / www.fvv.um.si / rV/arhiv/2014-2/05_Ticar.pdf, accessed on October 21th , 2019 at 9:32 A.M

3 Trstenjak, V. (2003). Pravne osebe. Ljubljana: GV zalożba, p.207-210., See also Tičar, B. Op., Cit.,p. 167 accessed on October 21th, 2019 at 2.34 P.M.

4 Tičar, B. Op., Cit., accessed on October 21th, 2019, 3.10 P.M

5 Benito, J. L. (1955). The Legal Personhood of Companies. Private Law Publisher, p 42 See alsoAdriano, E., Op., Cit., p. 108

6 Benito, J. L., Op., Cit., p.32 
States recognize the legal personality of legal entities through specific statutes. ${ }^{7}$ According to Bryant Smith, legal entities are subjects with rights and obligations. In order to have standing to assert legal rights or to enforce legal obligations, legal entities must have legal personality. According to Trstenjak, in Bojan Tičar, there are basic requirement that must be fulfilled by a legal entity in order to achieve the status of a a legal personality: 1) There must be specific purpose for legal entity establishment; 2) There must be a specific goal of the legal entity; 3) There must be management or other entities to carry out the purpose of the legal entity; and 4) There must be an organization accepted by law in forming the legal entity. ${ }^{8}$

Legal personality creates legal capacity, the ability to conduct legal transactions. When, legal personality is established, a legal entity engages with other parties in legal relations. It is appropriate in order to define legal personality in abstract legal relations or fulfills the requirements to become the party in legal relations. ${ }^{9}$ Furthermore, Bohinc and Tičar argued that legal personality of legal entity must fulfill the following requirements: 1) A legal entity has movable assets and real assets; 2) A Legal entity has property rights and appurtenant obligations; 3) Legal entity has the capacity to sue or be sued; and 4) a legal entity has responsibility for its assets. ${ }^{10}$

From another perspective, Fransisco Carnelutti posits that a legal entity is observed and likened to a triangular pyramid. According to him, a legal entity in this triangular pyramid context is a knot formed by the confluence of personal interest (economic element) and subjective rights (legal element) which are united in a legal relationship. In his opinion, legal entities are melting points between economic elements and legal elements. This relationship is illustrated in

7 Tičar, B., Op.,Cit.,p.174

8 Trstenjak, Op.,Cit., p. 208-209, See also, Tičar, Op.,Cit., p. 169

9 Smith, B. (1928). Legal Personality. The Yale Law Journal, 3, 283-299. Retrieved from https: / / www.jstor.org/stable/789740, accessed on October 25th 2019, 9.27 A.M.

10 Bohinc, R., \& Tičar, B. . (2006). Upravno Pravo- Splosini del. Ljubljana: Fakulteta za varnostne vede, p. 175-176 See also Ticar. Op.,Cit., p. 169-170 
Graphic $1 .^{11}$

Graphic 1. Legal entities are melting points between economic elements and legal elements

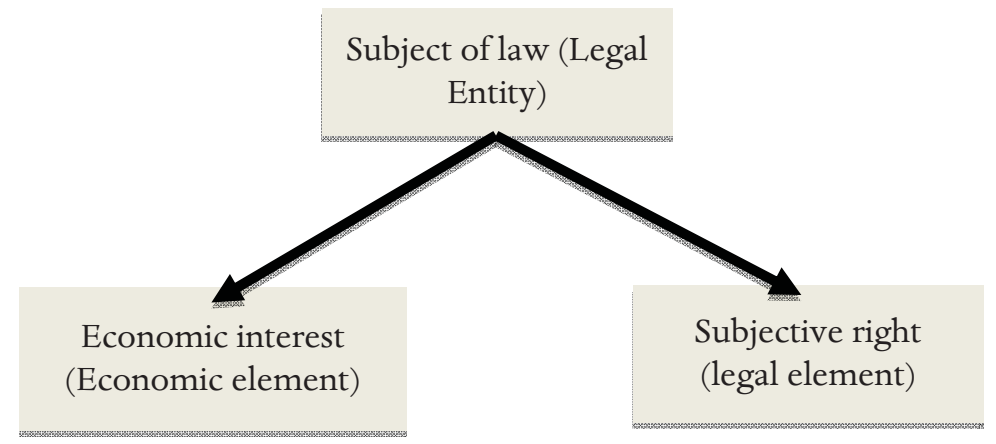

Carnelutti classified a juridical personas not only a person who is considered individually, but also by the collective interests, which is the interest of unifying with a common goal. He also stated that a collective legal entity is formed when economic elements and legal elements of association of people are the basic principles of collective interest unification. From Carnelutti's opinion, it is learned that elements of legal entity are: 1) legal capacity; 2) juridical personality; 3) economic element and; 4) legal element (subjective rights). ${ }^{12}$ Similarly, in Hans Kelsen's opinion, a legal entity must have the capacity to conduct legal acts. He argues that legal order gives rights and obligations to legal entities consisting of bodies or members of legal entitiesthat are formed and regulated by articles of association and can be described by legal entities'goals to profit from the personification of corporate's article of association. According to Kelsen, the elements of e establishing a legal entity are as follows: (1) the organization or artificial person; (2) conduct; (3) legal capacity; (4) subjective rights; (5). obligations; (6) will; and (7) juridical personality. ${ }^{13}$

Meanwhile, as the satisfaction of the aforementioned elements creates legal entities, in order to take legal action, legal entities re-

11 Carnelutti, F. (1955). General Theory of Law . Private Law Publisher, p.104

12 Ibid., p.105

13 Kelsen, H. (1967). Pure Theory of Law. (K. Berkeley, Trans.) California: University of California Press, p.178 
quire participation from other subjects of law (natural persons). In practice, the actions of legal entities have to be in line with the legal order. The legal order obligations are forms of recognition of legal entity status which is defined as the subject of law characterized by special legal capacity. A legal entity's actions may create rights and obligations such as property rights and its obligation to respect and obey the applicable laws and regulations. ${ }^{14}$

In the other experts' perspectives, legal entities can be classified based on the characteristics of the entities themselves. Grafenaur and Brezovnik, in Bojan Tičar, stated that with regard to the organizational purpose and operations, legal entities are divided into three categories, namely: 1) Territorial legal entities in the public sector; 2) Functional legal entities in the public and private sectors; and 3) voluntary-associative legal entities in the private sector operating in the public or private interest. ${ }^{15}$

According to Shaw, in Bojan Tičar, States are classified as legal entities due to states legal personalities recognized by other states and consequently from international legal orders. ${ }^{16}$ States have independent territory which has legal personality included within the scope of a state legal entity's authority. Bocan Tičar argued that states (governments) are legal entities, namely territorial legal entities. Territorial legal entities (the public sector) are legal entities which conduct activities in defined territories, and are in charge to promote the public interest within their territories. The main characteristic of territorial legal entities (public sector) is that the authority of the territorial legal entity is granted by the law. The authority, or sociologically speaking, power, for the territorial legal entity to enforce its will on other parties. This means that a territorial legal entity is a type of legal entity that is subordinate to the public interest.

Moreover, territorial legal entities (the public sector) have fun-

14 Ticar., Op.,Cit., p. 170-171

15 Grafenauer, B., \& Brezovnik, B. . (2006). Javna Uprava. Maribor: Pravna fakulteta, p.153-155 See also Ticar, Op., Cit., p.172-173

16 Shaw, M. N. (2003). International law. Cambridge: Cambridge University Press, p.82-84 See also Ticar, Op., Cit.,.p. 169 
damental functions including implementating regulations and fostering constituents' prosperity. In order to run their activities to create prosperity in the society, territorial legal entities conduct essential government services such as general public security and property protection, as well as political and economic functions. In addition, territorial legal entities (public sector) are characterised with their political authority within a constitutional framework and legal provisions in executing their duties. ${ }^{17}$

Basically, territorial legal entities conduct social services in the public interest, and importantly, not for profit. Nevertheless, such entities do not operate purely as non-profit organizations. Rather, public legal entities generate revenues from regular business operations. Therefore, although territorial legal entities do not seek profit for personal gain, these entities participate in and have an effect on commercial markets.

Profitable activities conducted by territorial legal entities are not prohibited by law, but are onlya secondary interest. The main priority of these entities is for the social good. Such activities are authorized as long as they do not confer benefit on individuals. This goal is different from commercial enterprises where personal gain is the primary goal; profit maximization and dividends for shareholders. ${ }^{18}$

\section{The Ability to Own and Protect Trademarks as a Subject to Different Systems}

Each nation maintains Trademarks that are defined in article 15, paragraph (1) of the Agreement on Trade-Related Aspects of Intellectual Property Rights (the "TRIPs Agreement").Trademarks shall be:

Any sign, or any combination of signs, capable of distinguishing the goods or services of one undertaking from those of other undertakings, shall be capable of constituting a trademark. Such signs, in particular words including personal names, letters, numerals, figurative elements and combinations of colures as well as any combination of such signs, shall be eligible for registration as trademarks. Where signs are not inherently capable of distinguishing the relevant goods or services,

17 Ibid.

18 Ibid. 
Members may make registrability depend on distinctiveness acquired through use. Members may require, as a condition of registration, that signs be visually perceptible.

This article specifically defines trademarks as symbols or combination of words and symbols distinguishing goods or services one and another. Such marks may consist of such elements of words as names, letters, numbers, figural elements or combinations of colors and combinations of symbols, that meet the registration conditions. Member states to the TRIPs Agreement may make registrability depending on the distinctiveness in use. Member states may require, as a condition of registration, that signs be visually distinctive.

Trademarks may be protected based on use or registration, both protections of which have already been developed. Nevertheless, nowadays, trademark protection systems generally combine both of these two elements of form a protection approach. ${ }^{19}$ The Paris Convention for The Protection of Industrial Property of March 20,1893 (the "Paris Convention"), particularly Article 6, stated:

(1) The conditions for the filing and registration of trademarks shall be determined in each country of the Union by its domestic legislation;

(2) However, an application for the registration of a mark filed by a national of a country of the Union in any country of the Union may not be refused, nor may a registration be invalidated, on the grounds that filing, registration, or renewal, has not been effected in the country of origin.

(3) A mark duly registered in a country of the Union shall be regarded as independent of marks registered in the other countries of the Union, including the country of origin.

The Paris Convention obliges the state parties to provide protection for registered trademarks. More than 100 state parties ratified this convention. Almost every state in the world has provided trademark registration as a protection for commercial intellectual property. Despite the legal protections afforts for registeration, trademark protection through "use" is still applicable and plays animportant role.

19 World Intellectual Property Organization. (1993). Introduction To Trademark Law \& Practice ( The Basic Concepts) (A WIPO Training Manual) (2nd Ed.). Geneva: WIPO Publication,p.10-11 
However, for states that recognize trademark protection through use, the registration only confirms trademark right through use, trademark registration confirms the rights and protections. Consequently, a first user has priority in a potential trademark dispute, not the person who was first to register the trademark. Moreover, the use has an important influence in many other aspects of the registration procedures and also in trademark dispute settlements especially for legal defense of registered trademarks before competent courts. ${ }^{20}$

According to Viorel Roș at al, in George-Mihai, there are three doctrines in trademark protection systems and trademark right acquisition: (1) the first to "use" system (realist or declarative); (2) the first to file system (Constitutive or attributive); and the mixt system (or dualist). ${ }^{21}$ Declarative systems award trademark rights to the first person who uses the trademark in trade and commercial activity. However, declarative systems do not exclude trademark registration, but rather, the Impact of a trademark application declarative system jurisdictions differ from the rights in constitutive systems (Trademark registration application). In other words, trademark use has a legal effect distinction and separate from the legal effect of trademark application. ${ }^{22}$ The manner in which trademark protection is acquired in such systems, identify the objective requirement that the use of trademarks in the public arena and are also impose a subjective requirement that trademark use in public is both purposeful and intentional. Both requirements must be factually and legally established. ${ }^{23}$

In the attributive or constitutive systems, trademark rights are acquired through registration in national, regional, or international intellectual property offices. Therefore, trademark rights inure to the first person who officially registers a legally cognizable trademark

20 Ibid.,p.10-11

21 Viorel Roș, Octavia Spineanu-Matei, Dragoș Bogand. (2003). Dreptul Proprietății Intelectuale. Dreptul Proprietății Industriale. Mărcile și indicațiile geografic. Bucharest: All Beck Publishing, p.16 See Also, George-Mihai IRIMESCU. (2017) . Trademark Protection Systems- Use Vs. Registration, Bucharest, University of Bucharest, p. 627-638.

22 Ibid

23 Ibid 
with distinctiveness characteristics, although a prior user is protected from infringement actions for use prior to registration. ${ }^{24}$

Mixt systems are those that combine both features of the attributive system and the declarative system, as legal effects are granted both to the factual existence of the trademark and to the act of trademark registration. Such a system is the delayed attributive system, applicable, according to the doctrine, to the United Kingdom system, according to which the declarative application turns, after a certain period of time, intodefinitive proof of the trademark right for the proprietor of the filed trademark. ${ }^{25}$

\section{The DIY Government as the lawful owner of the Jogjamark and $100 \%$ Jogja trademarks}

The government of the Special Region of Yogyakarta as municipal organization in structure was established by the Act No. 3 of 1950 concerning the establishment of the Special Region of Yogyakarta. The establishment of the Special Region of Yogyakarta not only made it a public municipals organization, by also a legal entity.

The Local Government of Special Region of Yogyakarta as a legal entity is the manifestation of plurality of individuals joined collectivity in order to achieve common goals. Plurality of individuals is manifested by the existence of this local government agency, let by the Governor of the Special Region of Yogyakarta as Head of the Local Government of Special Region of Yogyakarta who run governmental activities in the jurisdiction area of the Special Region of Yogyakarta purposed of creating prosperity. In this context, the Local Government of the Special Region of Yogyakarta as a legal entity is not only acollective manifestation of individuals, it also is established based on operations as a legal personality. The existence of this legal personality is based on the requirement needed to be a legal entity. The local government of the Special Region of Yogyakarta, observed in Benito's viewpoint, essentially that it fulfills the requirement as a 
Table 1. The Suitability of the Legal Entity Requirement according to Benito and Elements of the Local Government of the Special Region of Yogyakarta

\begin{tabular}{ll}
\hline \multicolumn{1}{c}{ Benito } & \multicolumn{1}{c}{ Local Government of Special Region of Yogyakarta } \\
\hline $\begin{array}{l}\text { Plurality of } \\
\text { Individuals }\end{array}$ & $\begin{array}{l}\text { Consisting of the collective population who act as the gov- } \\
\text { erning body in the special region of the Yogyakarta Region }\end{array}$ \\
\hline Cooperation & $\begin{array}{l}\text { There is a cooperation in an organization or local govern- } \\
\text { ment agency of the Special Region of Yogyakarta }\end{array}$ \\
\hline Organization & $\begin{array}{l}\text { The Existence of the Local Government agency who is } \\
\text { responsible to the govern the Special Region of Yogyakarta. }\end{array}$ \\
\hline $\begin{array}{l}\text { Exclusive } \\
\text { patrimonial } \\
\text { capacity }\end{array}$ & $\begin{array}{l}\text { There is a capacity under the applicable law to own and } \\
\text { manage assets by the Governor of the Special Region of } \\
\text { Yogyakarta }\end{array}$ \\
\hline porporate & $\begin{array}{l}\text { The Government of the Special Region of Yogyakarta was } \\
\text { established in order to run the holdings of Governmental } \\
\text { affairs for the prosperity of society in the Special Region of } \\
\text { Yogyakarta. }\end{array}$ \\
\hline
\end{tabular}

legal entity. This understanding is acquired by paying attention to the existence of a suitable legal entity in accordance with Benito's opinion and the elements of the Local Government of the Special Region of Yogyakarta. The suitability is illustrated in Table 1.

Table 2. The Suitability of Legal Entity Requirement according to Bohinc and Elements of Local Government of Special Region of Yogyakarta

\begin{tabular}{ll}
\hline \multicolumn{1}{c}{ Bohinc and Tičar } & $\begin{array}{l}\text { Local Government of Special Region of Yogya- } \\
\text { karta }\end{array}$ \\
\hline $\begin{array}{l}\text { Legal entity has mov- } \\
\text { able goods and real } \\
\text { assets }\end{array}$ & $\begin{array}{l}\text { The capacity to own Real assets and movable } \\
\text { goods that are managed by Local Government of } \\
\text { Special Region of Yogyakarta. }\end{array}$ \\
\hline $\begin{array}{l}\text { Legal entity has prop- } \\
\text { erty rights and bears } \\
\text { appurtenant legal } \\
\text { obligations }\end{array}$ & $\begin{array}{l}\text { The ownership right over real assets which are } \\
\text { managed by the special region of Yogyakarta and } \\
\text { local government of the special region of Yogya- } \\
\text { karta and bears the obligation to build prosperity } \\
\text { for the people in the Special Region of Yogyakarta. }\end{array}$ \\
\hline $\begin{array}{l}\text { Legal entity can sue and } \\
\text { be sued }\end{array}$ & $\begin{array}{l}\text { The Local Government of the Special Region of } \\
\text { Yogyakarta can sue or be sued before a competent } \\
\text { court. }\end{array}$ \\
\hline $\begin{array}{l}\text { Legal entity is respon- } \\
\text { sible for its entireasset } \\
\text { portfolio }\end{array}$ & $\begin{array}{l}\text { The Local Government of the Special Region of } \\
\text { Yogyakarta has responsibility over its obligations. }\end{array}$ \\
\hline
\end{tabular}


Meanwhile, the requirement that the Local government of the Special Region of Yogyakarta has a legal personality isexpressed by Bohinc and Tičar. Such legal entity requirement is satisfied by the mandate and structure of the local government of the Special Region of Yogyakarta, specifically that the Local Government of the Special Region of Yogyakarta has a legal personality and is classified as a legal entity in accordance with Bohinc and Tičar's theories. To be more clear, it is illustrated in Table 2.

A similar concept is also applicable under the theory expressed by Trstenjak concerning the requirement of a legal entity. The Local Government of the Special Region of Yogyakarta is considered to have a legal personality and is also classified as legal entity, as seen in Table 3.

Table 3. The Satisfactionof the Legal Entity Requirement according to Trstenjak and The Elements of Local Government of Special Region of Yogyakarta

\begin{tabular}{|c|c|}
\hline Trstenjak & $\begin{array}{l}\text { Local Government of Special Region of Yogya- } \\
\text { karta }\end{array}$ \\
\hline $\begin{array}{l}\text { There must be con- } \\
\text { crete objectives of the } \\
\text { legal entity }\end{array}$ & $\begin{array}{l}\text { The local government of the Special Region of } \\
\text { Yogyakarta was established with the purpose of } \\
\text { conducting the governmental affairs in special } \\
\text { region of Yogyakarta. }\end{array}$ \\
\hline $\begin{array}{l}\text { There must be means } \\
\text { to fulfill the legal en- } \\
\text { tity's objectives }\end{array}$ & $\begin{array}{l}\text { To fulfill its purpose, the local government of the } \\
\text { special region of Yogyakarta means that it is legally } \\
\text { mandated to work in the best interest of the public }\end{array}$ \\
\hline $\begin{array}{l}\text { There must be owner- } \\
\text { ship and management } \\
\text { of other bodies needed } \\
\text { to fulfillthe objectives } \\
\text { of the legal entity }\end{array}$ & $\begin{array}{l}\text { To fulfill its chartered purpose, the Local govern- } \\
\text { ment of the Special Region of Yogyakarta has } \\
\text { local government agencies which manage good } \\
\text { governance principles based on applicable laws and } \\
\text { regulations. }\end{array}$ \\
\hline $\begin{array}{l}\text { Having an organiza- } \\
\text { tional structure rec- } \\
\text { ognized by law in the } \\
\text { form of a legal entity }\end{array}$ & $\begin{array}{l}\text { The Local Government of the Special Region of } \\
\text { Yogyakarta has governmental bodies that were } \\
\text { established according to applicable laws and regula- } \\
\text { tions. }\end{array}$ \\
\hline
\end{tabular}

Having met the aforementioned elements, the Local Government of the Special Region of Yogyakarta can be classified as a public 
legal entity or territorial legal entity (the public sector). This entity is charged with municipal governments including Yogyakarta City, Sleman Regency, Bantul Regency, Kulon Progo Regency, and Gunung Kidul Regency. The Local Government of the special Region of Yogyakarta deals with the public activities of the region. Additionally, the Local Government of the Special Region of Yogyakarta is categorized as a territorial legal entity (public sector), i.e. possessing the authority to impose its will on subordinate parties (person or other legal person). Furthermore, the Local Government of Special Region of Yogyakarta has regulatory functions (with Regional House of Representatives), including executive Decrees of the governor.

The Local Government of the Special Region of Yogyakarta is a territorial legal entity (public sector) obliged to run governmental affairs, and ensure the public prosperity. In executing its duties and obligations, the Local Government of the Special Region of Yogyakarta has constitutional authority to promulgate regulations i.e. Organizations of Local Government Agency and the Regional House of Representative in order to fulfill its mandate.

As a public legal entity, the Local Government of the Special Region of Yogyakarta, has a legal personality given its legally cognizable identity. Therefore, the Local Government of the Special Region of Yogyakarta is able to act as a legal subject, both rights and obligations. The rights and obligations are reflected by its ability and mandated to hold properties as well as rights and duties related thereto. The article 5, paragraph (1), Law no. 3 of 1950, concerning the Establishment of the Special Region of Yogyakarta stated that "Each ownership either corporeal or incorporeal property and companies of Special Region of Yogyakarta, before the enactment of this law become the ownership of Special Region of Yogyakarta, and then may turn over the things to region under it.

Regarding incorporeal property, the local government of the special region of Yogyakarta has the authority to own and manage intangible property including Intellectual Property Rights. Intellectual Property Rights are the legal rights arising from the tangible manifestation of human thought. Usually, this legal right is categorized as 
an intangible asset that consists of; 1. ccopyright and related rights; 2. trademarks; 3. geographical indications; 4. industrial designs; 5. patents; 6. layout-designs (topographies) of integrated circuits; 7. protection of undisclosed information; 8 . control of anti-competitive practices in contractual licences. ${ }^{26}$

Under current practice, the Local Government of the Special Region of Special Region of Yogyakarta has become the holder of the registered trademarks Jogjamark and 100\%Jogja. This ownership has been proven through the following two aspects: 1)The certificate of ownershipof the trademark rightsto Jogjamark and 100\%Jogja; and 2) The availability of the Special Region of Yogyakarta Governor's Decree No. 21 of 2017 concerning on concerning the utilization of trademarks Jogjamark, 100\%Jogja, and Jogjatradition, as Local Product Co-Branding (here in after in this paper stated as Special Region of Yogyakarta Governor's Decree No. 21 of 2017).

The ownership of the registered trademarks Jogjamark and $100 \%$ Jogja by the Local Government of the Special Region of Yogyakarta is proven by trademark certificate of Jogjamark within registration number IDM000631943 filed August $6^{\text {th }} 2018$, and trademark certificate of $100 \%$ Jogja within registration number IDM000550254 filed May $17^{\text {th }} 2017$. Both trademarks have already been registered with the Directorate General of Intellectual Property Ministry of Law and Human Rights, Republic of Indonesia.

As demonstrated by trademark certificates in Figure 1 and 2, the Local Government of the Special Region of Yogyakarta owns the exclusive trademark rights of to Jogjamark and 100\%Jogja in accordance with Law no. 20 of 2016 concerning Trademark and Geographical Indication. Therefore, the Local Government of the Special Region of Yogyakarta has the exclusive right to use and license Jogjamark and $100 \%$ Jogja. To codify this arrangement, the Local Government of the Special Region of Yogyakarta has enacted Special Region of Yogyakarta Governor's Decree No. 21 of 2017. This Decree resulted from the efforts of the Local Government of the Special Region of

26 Agreement On Trade-Related Aspects of Intellectual Property Rights (TRIPs Agreement) 
Figure 1. Trademark Certificate of Jogjamark
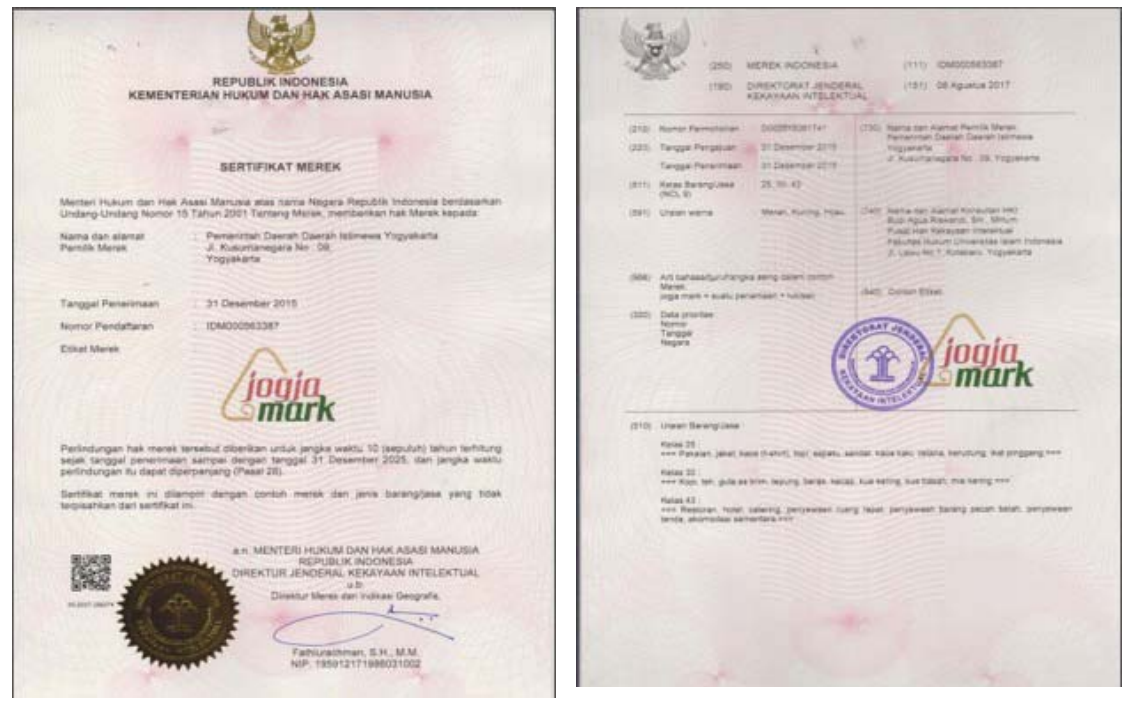

Figure 2. Trademark Certificate of 100\%Jogja
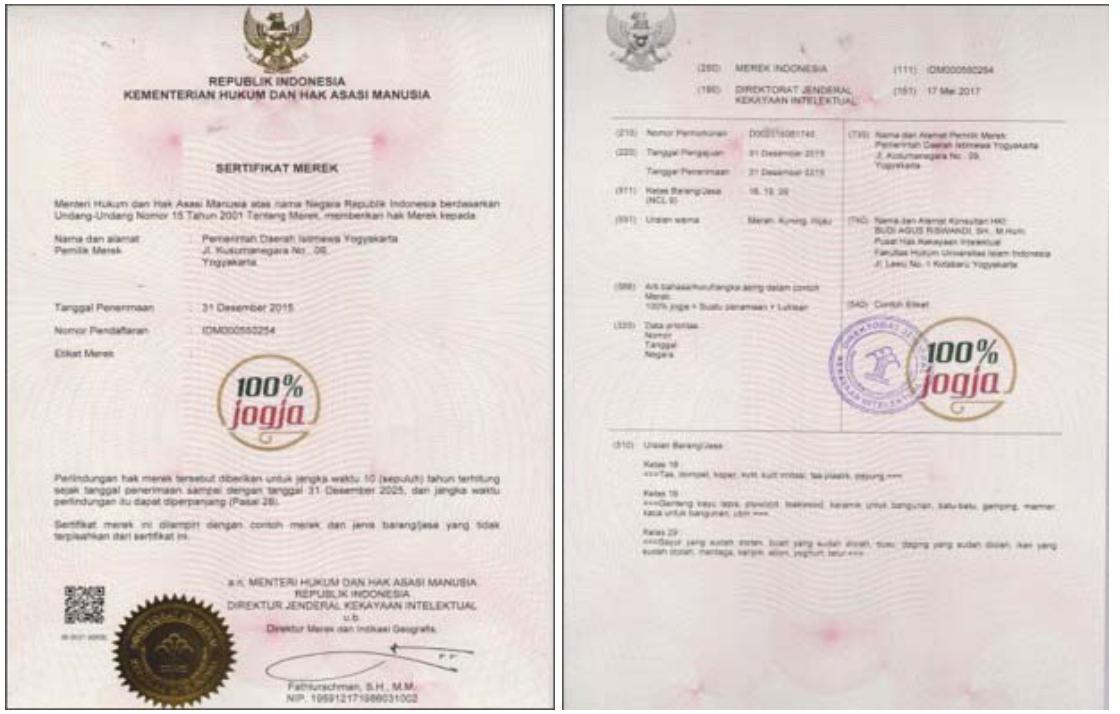

Yogyakarta to manage the exclusive rights of these trademarks. In addition, as longas as the management of this intellectual property is concerned, the regulations specify the definition and meaning of trademarks, the ownership of trademarks, utilization of trademarks, 
requirements and procedures for trademark utilization, obligations of the trademark users or licensees, utilization monitoring, and promotion and sanction of trademark infringement.

It is demonstrated from the explanation above that the Local Government of the Special Region of Yogykarta as a public legal entity acts as a subject of law proven by ownership over Jogjamark and $100 \%$ Jogja. The ownership of trademark rights are integral in the ownership of incorporeal property. The ownership of Jogjamark and $100 \%$ Jogja are in accordance with the theory of public legal entities, valid and justified by law.

\section{E. The Role of DIY Government in Exercising the Ownership for the Benefit of the Local People}

Article 1, section (2) of the Governor Regulation of the Special Region of Yogyakarta No. 21 of 2017 states that Jogjamark is symbol and/or characteristic exclusive to local products of the Special Region of Yogyakarta. Similarly, Article 1, section 3 of the Governor's Regulation of the Special Region of Yogyakarta No. 21 of 2017 prescribes that $100 \%$ Jogja is a symbol indicating that the products is affixed and are made locally in Yogyakarta. Jogjamark delineates local products that use raw materials partly or entirely from outside the region, but produced in the Special Region of Yogyakarta. ${ }^{27}$ Meanwhile 100\%Jogja is used to identify local products made entirely within the DIY and from raw materials from the DIY. ${ }^{28}$

The shapes of the marks are also designed to convey additional meaning. Jogjamarkis triangular in tribute to Mount Merapi, the Keraton (The Yogyakarta Sultan's Palace) and the Agung Mosque. The colors refer to dominant locally used colors and the letters use the same font as another commonly used mark, Jogja Istimewa (special Jogja). Moreover, the $100 \%$ Jogja trademark is circular, a classic form of local stamps. A stamp is one of the tools to certify documents and

27 Article 6 paragraph (1) Governor Regulation of Special Region of Yogyakarta No. 21 of 2017.

28 Article 6 paragraph (2) Governor Regulation of Special Region of Yogyakarta No. 21 of 2017. 
Figure 3. Jogjamark and100\%Jogja trademarks
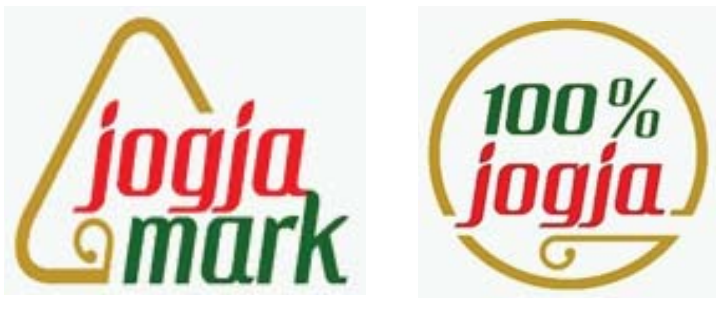

therefore appropriate with "certification" of 100\%Jogja. In addition, circle can also be interpreted as a symbol of sustainability, continuous and without interruption.

By registering the Jogjamark and 100\%Jogja trademarks, the Local Government of Special Region of Yogyakarta claims exclusive rightsto them. This claim is based on two applicable legal foundations: (1) Article 42 paragraph (2) Law No. 20 of 2016 concerning Trademarks and Geographical Indications, giving registered trademark owners the right to use its marks by itself or to give licenses to third parties to utilize the trademarks; and (2) Article 4 paragraph (2), the Special Region of Yogyakarta Governor's Decree ofYogyakarta No. 21 of 2017, which grants the "exclusive right of Jogjamark, $100 \%$ Jogja and Jogja tradition owned by Local Government". Based on these two provisions, the Local Government of the Special Region of Yogyakarta's ownership of the exclusive rightsto the Jogjamark and $100 \%$ Jogja trademarks can be classified as: First, the Local Government of the Special Region of Yogyakarta may utilize these trademarks independently; Second, the local Government of the Special Region of Yogyakarta; and third, the Local Government of Special Region of Yogyakarta can prohibit third parties from utilizing these trademarks without consent.

The Local Government of the Special Region of Yogyakarta may utilize its exclusive rights by licensing the Jogjamark and 100\%Jogja trademarks to businesses which produce their products in the Special Region of Yogyakarta. These businesses can obtain a license for each person or group or community that produces products in the Special Region of Yogyakarta. In order to obtain a license, each person/ 
group/ community may submit an application to the Local Government of the Special Region of Yogyakarta, specifically to the Intellectual Property Management Office of Industrial and commercial agency, Special Region of Yogyakarta, or by submitting an application online through the JOGJAKI website (jogjaki.jogjaprov.go.id).

The license application has to fulfil two essential requirements: 1) The applicant has to possess commercial permits and certificates of company registration; and 2) Proof of the provenance of the raw materials and fabrication processes, as well as a Product Standard Warranty. Applicants must also provide proof of the continuity of their production and raw materials sourcing, subject to inspection and verification. Nevertheless, the review process is quite quick; if the required documentation is not complete, the Local Government of Special Region of Yogyakarta will return the application documents to applicants to be revised, no more than three (3) working days after the documents are submitted.

The Local Government of the Special Region of Yogyakarta has only a 12-working day window to accept or reject the license applications. If a license application is accepted, the Local Government of Special Region of Yogyakarta will Issue the applicable license approval which is valid for 3 from the date of issuance, and can be extended. If a license application is rejected, the Local Government of

Graphic 2. Flow of co-branding application of Jogjamark and 100\%Jogja

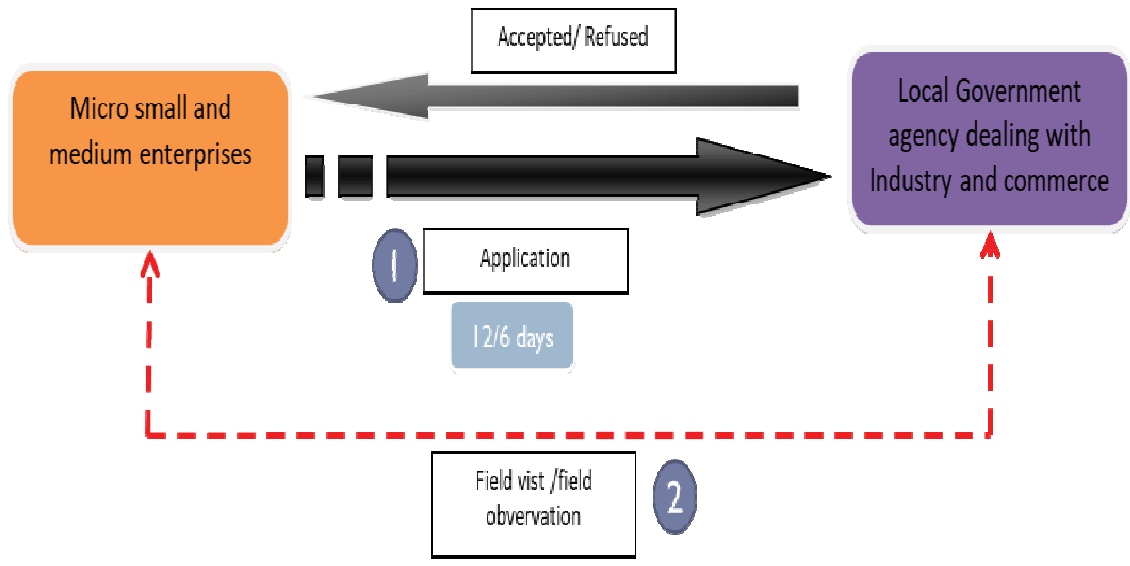


Graphic 3. Monitoring system of co-branding Jogjamark and 100\%Jogja

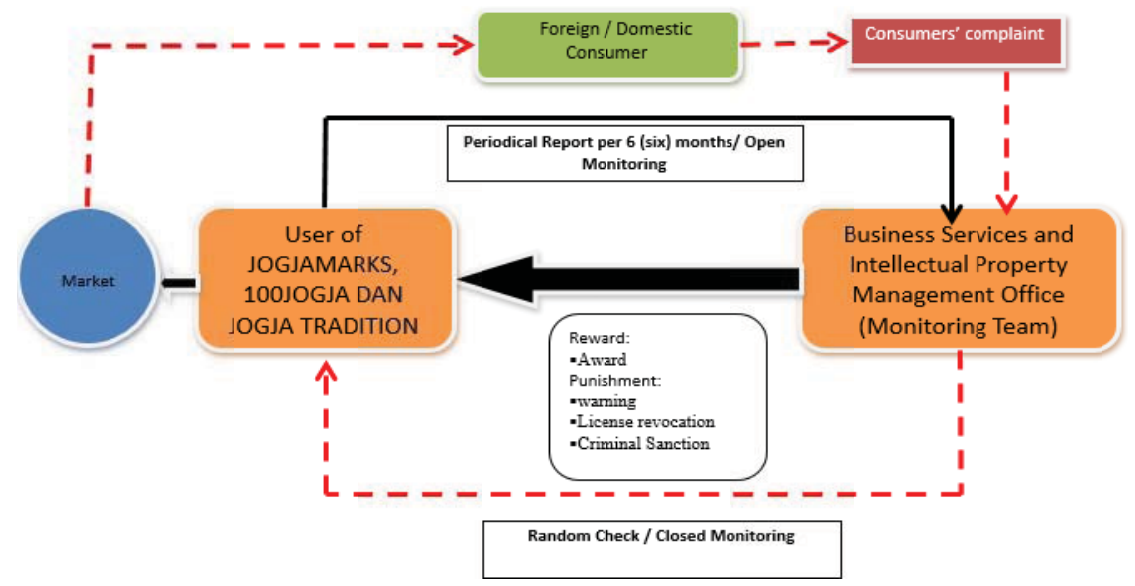

the Special Region of Yogyakarta will provide a written notification including the reason or reasons for rejection.

As soon as a license is of Jogjamark and 100\%Jogja is granted, the licensee of business is continually monitored. The Monitoring System for licensee of the Jogjamark and 100\%Jogja trademarks is conducted to maintain the reputation and trust of consumers, and society overall, toward local products of the Special Region of Yogyakarta. Monitoring consists of two models as follows: First, Open monitoring through reports from consumers or businesses themselves; and Second, close monitoring through random sampling and random checks.

In practice, the Jogjamark and 100\%Jogja registered trademarks have been in use for at least 2 years. Until December 2019, the number of businesses who have licensed Jogjamark and 100\%Jogja trademarks have exceeded 180. Of these businesses, 56 come from the Bantul Regency, 7 business from the Gunung Kidul Regency, 19 from the Kulon Progo regency, 40 from the Sleman Regency, and 58 from Yogyakarta City. Most business have accessed the service through jogjaki.jogjaprov.go.id. The spread of businesses licenses the Jogjamark and 100\%Jogja trademarks is demonstraed in Chart 1.

It is learnt from the distribution of businesses, based on Classification of goods, the the $100 \%$ Jogja licensees constitute $41.1 \%$. The 


\section{Budi Agus Riswandi}

Chart 1. Statistical data of trademark licenseesof Jogjamark and 100\%Jogja based on Domicile

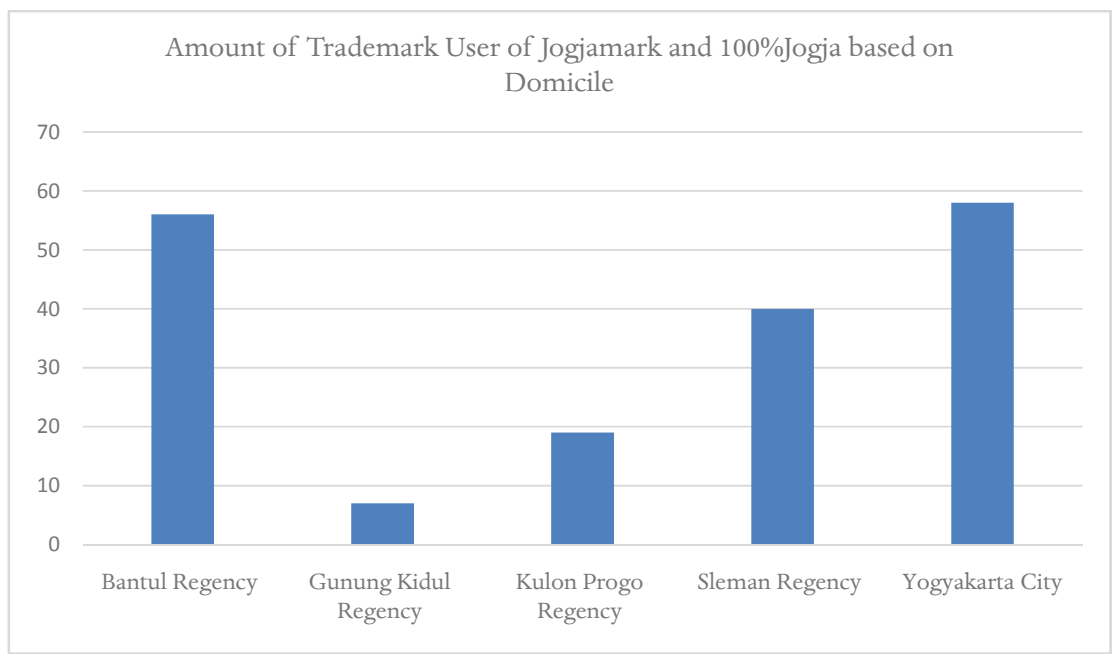

Chart 2. Amount of trademark based on good classification

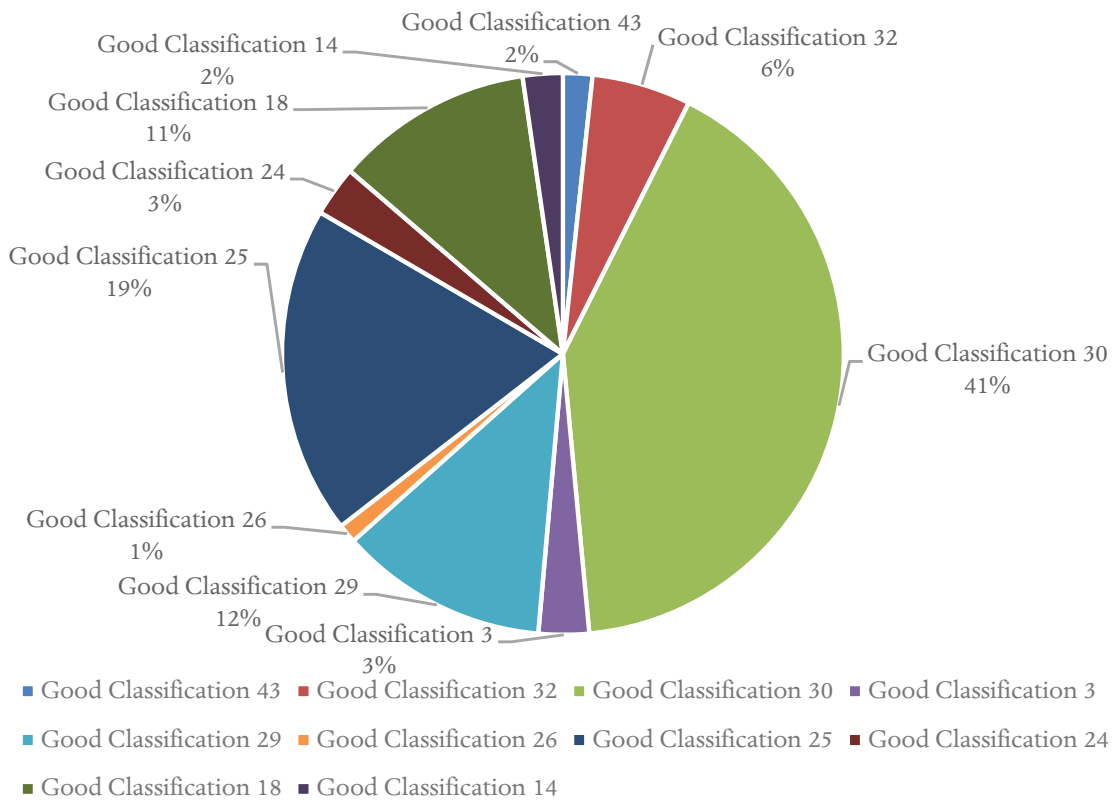

use of the Jogjamark and 100\%Jogja marks can be seen in Chart 2.

Practically speaking, several benefits have resulted from the trademark utilization of Jogjamark and 100\%Jogja. For businesses, 
the benefits include pride concerning on the product that is traded in markets, and information that the products are certified to have originated from the Special Region of Yogyakarta. ${ }^{29}$ Meanwhile, for Local Governments of the Special Region of Yogyakarta, the certification of local products provide authenticity of Gotong Royong (mutual cooperation). ${ }^{30}$

Indeed, the system is not flawless and there are often complications resulted from: First, requirements and documents provided by businesses are often incomplete; Second, many products are not authentic. One example of this refusal in the condition of businesses actors do not produce products in the Area of Special Region of Yogyakarta, but rather act as re-seller. ${ }^{31}$

Meanwhile, the practice of the utilization of the Jogjamark and $100 \%$ Jogja trademarks faces several obstacles. The ones that are faced by local government of the special region of Yogyakarta come from the businesses themselves. They sometimes fail to fulfil administrative requirement to awarding trademark Jogjamark and 100\%Jogja. Therefore, they have to be provided with information and understanding. They also need to be encouraged by the Local Government of Special Region of Yogyakarta in order to fulfill the requirements. Additionally, the obstacles with respect to online registration which is inseparable with the main website of Local Government of Special Region of Yogyakarta. In the condition when the website of the Local Government is in trouble, online registration is constrained. To solve the obstacles, the Local Government of Special Region of Yogyakarta carries on persuasive efforts in order to encourage business actors to concern with the administrative affairs i.e. by continuously increasing communication among Local Government of Special Region of Yogyakarta and Business Actors. Besides, the Local Government of the Special Region of Yogyakarta conducts of socialization

29 Interview with Sri Purwatningrum and Surati, Business Actors in Special Region of Yogyakarta,dated on November $10^{\text {th }} 2019$ at 9.10 A.M

30 Interview with Ida Sulastri Lestari, Official Staff of Intellectual Property Management Office of Industrial and commercial agency, Special Region of Yogyakarta, dated on November $13^{\text {th }} 2019$, at 9.10 A.M

31 Ibid 
and promotion of products using the trademarks of Jogjamark and $100 \%$ Jogja. ${ }^{32}$

\section{F. Conclusion}

The Local Government of the Special Region of Yogyakarta as a public legal entity is subject to legal rights and obligations. In this context, the Local Government of the Special Region of Yogyakarta has rights over its property for corporeal assets or incorporeal assets. By ownership of such rights, the Local Government of Special Region of Yogyakarta may become subject of law owning the corporeal property and incorporeal property including intellectual property right, especially after the registeratiom of the trademarks Jogjamark and $100 \%$ Jogja. Therefore, the trademark certificates is published in the name of the Local Government of Special Region of Yogyakarta by Directorate General of Intellectual Property Ministry of Law and Human Rights of the Republic of Indonesia. While the local government of the region has become a public legal entity, it is officially and legally the owner of trademark of Jogjamark and 100\%Jogja accordance to the applicable law.

The implementation of the Jogjamark and 100\%Jogja trademarks by the Local Government of Special Region of Yogyakarta is running by applicable normative provision i.e. the Law no 20 of 2016 concerning Trademark and Geographical Indication Juncto the Special Region of Yogyakarta Governor’s Decree No. 21 of 2017 concerning on The Utilization of Trademark of Jogjamark, 100\%Jogja and Jogjatradition as Local Product Co-Branding. Normativelly, the utilization of trademark Jogjamark and 100\%Jogja has been regulated from the ownership, utilization and monitoring. It provides regulation and management on utilization of trademark Jogjamark and 100\%Jogja which is directed and managed properly. In practice, in the implementation of trademark of Jogjamark and 100\%Jogja, there are several grounds for refusal of the application of trademarks Jogjamark and 100\%Jogja. First, the obstacle that results from the business actors themselves 
who fail to fulfill the administrative requirement to awarding trademark Jogjamark and 100\%Jogja. Second, the obstacle concerning the online registration. To solve such problems, the local government, therefore, rely on enhanching communication with business actors as well as socialization and promotion of products using the trademarks of Jogjamark and 100\%Jogja.

\section{Bibliography}

Adriano, E. A. (2015). The Natural Person, Legal Entity or Juridical Person and Juridical Personality. The Penn State Journal of Law \& International Affairs, 4(1), 363-391. Retrieved from https: / / elibrary.law.psu.edu/jlia/vol4/iss1/17/

Aubelj, B. (2003). Pravo, . Ljubljana: Leksikon Cankarjeve zalożbe.

Balai Pengelolaan Kekayaan Intelektual Dinas Perindustrian And Perdagangan Daerah Istimewa Yogyakarta. (2017). Implementasi Co Branding Pada Produk-Produk Daerah. Balai Pengelolaan Kekayaan Intelektual Dinas Perindustrian And Perdagangan Daerah Istimewa Yogyakarta. Yogyakarta: Balai Pengelolaan Kekayaan Intelektual Dinas Perindustrian And Perdagangan Daerah Istimewa Yogyakarta.

Benito, J. L. (1955). The Legal Personhood of Companies. Private Law Publisher.

Bohinc, R., \& Tičar, B. . (2006). Upravno Pravo- Splosini del. Ljubljana: Fakulteta za varnostne vede.

Carnelutti, F. (1955). General Theory of Law . Private Law Publiser.

Grafenauer, B., \& Brezovnik, B. . (2006). Javna Uprava. Maribor: Pravna fakulteta.

Kelsen, H. (1967). Pure Theory of Law. (K. Berkeley, Trans.) California: University of California Press.

Lestari, I. S. (2019, November 13). Implementasi Merek Jogjamark and $100 \%$ Jogja . (R. A. Putra, Interviewer)

Mihai, G. (2017). Trademark Protection Systems - Use Vs. Registration.Challenges of the Knowledge Society. Intellectual Property Law, 627-639. 
Okediji, R. L. (2016). Government as Owner of Intellectual Property? Considerations for Public Welfare in the Era of Big Data. VAND. J. ENT. \& TECH. L., 18(2), 331-362. Retrieved from https: / / www. jetlaw.org/wp-content/uploads / 2016/03/Okediji_SPE_7-FINAL.pdf

Salmond. (1916). Jurisprudence (5th ed.). London: Stevens and Haynes.

Savigny, F. C. (1840). Modern Roman Law System. (J. M. Poley, Trans.) Berlin: Veit.

Shaw, M. N. (2003). International law. Cambridge: Cambridge University Press.

Smith, B. (1928). Legal Personality. The Yale Law Journal, 3, 283-299. Retrieved from https: / / www.jstor.org/stable/ 789740

Tičar, B. (2016). Towards an Innovative Classification of Legal Persons. Journal of Criminal Justice and Security, 2, 164-177. Retrieved from https: / / www.fvv.um.si/rV/arhiv/2014-2/05_Ticar.pdf Trstenjak, V. (2003). Pravne osebe. Ljubljana: GV zalożba.

Viorel Roș, Octavia Spineanu-Matei, Dragoș Bogand. (2003). Dreptul Proprietătii Intelectuale. Dreptul Proprietății Industriale. Mărcile și indicațile geografic. Bucharest: All Beck Publishing.

World Intellectual Property Organization. (1993). Introduction To Trademark Law \& Practice ( The Basic Concepts) (A WIPO Training Manual) (2nd Ed.). Geneva: WIPO Publication.

\section{Regulation}

Paris Convention for the Protection of Industrial Property 1883

Trade-Related Aspects of Intellectual Property Rights 1994

Republic of Indonesia, Act No. 3 of 1950 concerning on the establishment of Special Region of

Yogyakarta as amended for several times by Act No. 9 of 1955 concerning on amendment of Act No. 3 JO. No 19 of 1950 on Establishment of Special Region of Yogyakarta State Gazette of the Republic of Indonesia of 1950 No. 3

Republic of Indonesia, Act No. 13 of 2012 concerning on Specialty of Yogyakarta, State Gazette 
of the Republic of Indonesia of 2012 No. 170, Additional State Gazette No. 5339Republic

of Indonesia, Act No. 20 of 2016 concerning on trademark and geographical indication, State Gazette of the Republic of Indonesia of 2016 No.252, Additional State Gazette No. 5953

Special Region of Yogyakarta Province, Governor Regulation No. 21 of 2017 concerning on The

utilization of Trademark of Jogjamark, 100\%Jogja and Jogjatradition as Local Product Co-Branding, Local Gazette of Special Region of Yogyakarta Province of 2017 No. 22. 